\title{
Insights into the Identity of the Putative Molecular Target of Infectious Bursal Disease Virus on Chicken Bursal Cells
}

\section{Hari Mohan Saxena* and Pushpinder Kaur}

Department of Veterinary Microbiology, College of Veterinary Science, GADVASU, Ludhiana, India

*Corresponding Author: Hari Mohan Saxena, Department of Veterinary

Microbiology, College of Veterinary Science, GADVASU, Ludhiana, India.
Received: September 29, 2020

Published: October 22, 2020

(C) All rights are reserved by Hari Mohan

Saxena and Pushpinder Kaur.

\begin{abstract}
Infectious Bursal Disease (IBD), caused by IBD virus (IBDV) is an acute, highly contagious immunosuppressive disease of chickens of 3 - 6 weeks of age which causes significant economic losses globally. Lymphoid cells in the bursa of Fabricius are the target cells of IBDV infection. However, the exact identity of the target molecule to which the IBDV binds on the lymphoid cells is still elusive. Immature B lymphocytes, dendritic cells and monocytes, the cells to which the IBDV binds, all express MHC II. Activation of lymphocytes enhances MHC II expression. We have found enhanced binding of IBDV to lymphocytes after activation which could possibly be due to increased expression of the putative target molecule on activation. LPS activation of B cells resulted in enhanced binding of IBDV as compared to the untreated cells. TGF $\beta$ treatment which downregulates MHC II expression, decreased IBDV binding on B cells. IFN $\gamma$ treatment, which upregulates MHC II expression, increased IBDV binding on B cells. Activation of T cells with Con A, which induces MHC II expression, led to IBDV binding on T cells. Thus, as suggested by the above findings, MHC II molecule may be the putative target for IBDV on chicken B cells.
\end{abstract}

Keywords: Infectious Bursal Disease; IBD Virus; Molecular Target; Bursa; Chicken B Cells; Lymphocytes

\section{Introduction}

Infectious Bursal Disease (IBD), also known as Gumboro disease, caused by IBD virus (IBDV) is an acute, highly contagious disease of young chickens of 3 - 6 weeks of age. Itis an immunosuppressive viral disease which causes a significant economic impact due to direct losses, as a result of mortality, and indirect losses as a consequence of immunosuppression, impaired growth etc. The disease is present in more than $95 \%$ of the OIE member countries [1]. It is enzootic in some areas of the world and is a constant threat to most birds reared domestically.

Lymphoid cells in the bursa of Fabricius are the target cells of IBDV infection. The infection results in lymphoid depletion and the final destruction of the BF is the predominant feature of the patho- genesis of IBD [2]. IBDV infection of susceptible chickens causes depletion of B cells by inducing the apoptosis of cells [3]. in bursa as well as in the thymus [4]. However, the exact identity of the target molecule to which the IBDV binds on the lymphoid cells is still elusive. The present study was planned to identify the surface molecule of chicken lymphocytes on which IBDV binds. We report here the new insight gained into the identity of the putative target of IBDV from our experimental studies.

\section{Materials and Methods}

Guidelines of the Institutional Animal Ethics Committee (IAEC), Guru Angad Dev Veterinary and Animal Science University (GADVASU), Ludhiana were followed in all the experiments with animals and birds. 


\section{Experimental animals}

A German Angora rabbit below six months of age and 4 albino mice from the Department of Livestock Production and Management, GADVASU, Ludhiana were used for raising hyperimmune serum against IBDV. The animals were reared in the Animal House of the Department of Veterinary Microbiology, GADVASU, Ludhiana following the guidelines of Institutional Animal Ethical Committee (IAEC). Permission for use of experimental animals was taken before the start of the experiment.

\section{Experimental birds}

Bursae and peripheral blood were collected for the experimental studies from the broilers of the age group of 6 - 8 weeks purchased from the GADVASU Poultry Farm, Ludhiana or the local abattoir.

\section{Infectious bursal disease virus preparation}

The live intermediate type strain vaccine (Ventri Biologicals, Pune) virus was propagated in chicken embryo fibroblast (CEF) cell line to ensure its infectivity.

Culture medium

Stock medium

The content of one vial of Dulbecco's Modified Eagle's Medium (Himedia Laboratories, Mumbai) was dissolved in $800 \mathrm{ml}$ of autoclaved triple glass distilled water (TGDW) and filtered through $0.22 \mu \mathrm{m}$ filter. The filtered stock was incubated at $37^{\circ} \mathrm{C}$ for $72 \mathrm{hrs}$ to ensure sterility and stored at $4^{\circ} \mathrm{C}$ till further use. A $10 \%$ solution of L-glutamine was prepared in TGDW, filtered and kept at $-20^{\circ} \mathrm{C}$. A $4.4 \%$ solution of sodium bicarbonate was prepared in $100 \mathrm{ml}$ of TGDW and autoclaved at $10 \mathrm{lb}$ pressure for 10 minutes. Newborn calf serum (Himedia, Mumbai) was used to prepare growth and maintenance media.

\section{Growth medium}

The growth medium (GM) was prepared with the following composition:

- $\quad$ Stock DMEM: $80 \mathrm{ml}$

- Fetal calf serum: $10 \mathrm{ml}$

- $\quad$ L-glutamine: $1 \mathrm{ml}$

- $\quad$ Sodium bicarbonate (4.4\%): $2 \mathrm{ml}$

- $\quad$ Gentamycin: $0.2 \mathrm{ml}(0.01 \mathrm{mg})$
- $\quad$ Nystatin: $10 \mu \mathrm{l}$ (100 units)

- $\quad$ TGDW: $7 \mathrm{ml}$.

The $\mathrm{pH}$ of GM was adjusted to 7.2 followed by filtration through $0.22 \mu \mathrm{m}$ filter. The GM was stored at $4^{\circ} \mathrm{C}$ after checking sterility by incubating it at $37^{\circ} \mathrm{C}$ for $72 \mathrm{hrs}$.

The composition of the maintenance medium was similar to the GM except that fetal calf serum was added at the rate of $2 \%$ instead of $10 \%$. Trypsin phosphate glucose versine (TPGV) solution was prepared and was subjected to Millipore filtration and stored in aliquots.

\section{Cell culture for propagation of virus}

Chicken embryo fibroblast (CEF) cell line was obtained from the Department of Animal Biotechnology and Genetics, GADVASU, Ludhiana. The cell line was sub-cultured in Dulbecco's Modified Eagle's Medium (Himedia, Mumbai) as per the standard method with some modifications. The cryovial containing cryopreserved cell line was taken out from the liquid nitrogen cylinder and thawed quickly in distilled water prewarmed at $37^{\circ} \mathrm{C}$. The content of the vial was then transferred to a centrifuge tube containing $10 \mathrm{ml} \mathrm{GM}$ and centrifuged at $1000 \mathrm{rpm}$ for 5 minutes. The supernatant was discarded and the cell pellet was suspended in $10 \mathrm{ml} \mathrm{GM}$ for transferring it to $25 \mathrm{~cm}^{2}$ tissue culture flask aseptically. A complete monolayer was formed in 48 to $72 \mathrm{hrs}$.

\section{Sub-culturing of CEF cell line}

A confluent monolayer of CEF cells in $25 \mathrm{~cm}^{2}$ tissue culture flask was subjected to sub culturing. GM was decanted and about $1 \mathrm{ml}$ of TPGV solution was added into the flask and kept for 30 seconds. The TPGV was then decanted and the flask was kept at $37^{\circ} \mathrm{C}$ for 5 minutes. The GM was added and the flask cell culture was separated by gentle pipetting to make uniform suspension. New flasks were seeded with these cells at the split ratio of 1:2. The second new flask was supplemented with $5 \mathrm{ml}$ of GM and incubated at $37^{\circ} \mathrm{C}$ for getting a complete monolayer.

\section{Cultivation of virus in cell culture}

The confluent monolayered tissue culture flasks were used for the virus inoculation. The growth medium was removed and the cell monolayer was washed twice with the maintenance medium. Virus stock in maintenance medium $(0.2 \mathrm{ml})$ was inoculated in the culture at $37^{\circ} \mathrm{C}$ and monitored daily for cytopathic effects (CPE) 
up to 4 - 5 days. At 5 days post inoculation, the monolayer was disrupted by repeated freeze thaw cycles and the suspension was clarified by low speed centrifugation. The supernatant fluid was harvested and the cell culture lysate was used as virus inoculum in the subsequent passage. The monolayer was infected as described earlier and second passaged virus/cell lysate was harvested, aliquoted and stored at $-20^{\circ} \mathrm{C}$ until used further (Figure 1).

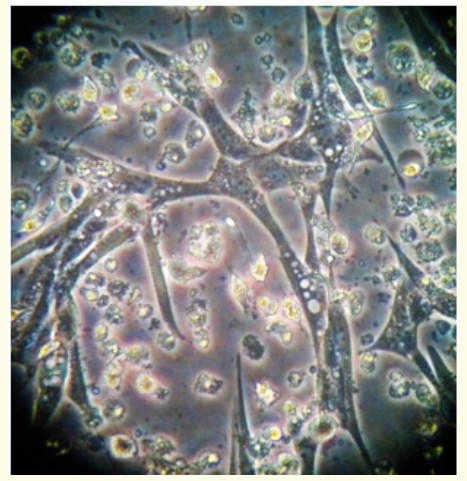

Figure 1: CEF cell line showing CPE caused by IBD Virus.
Raising of hyperimmune serum against IBDV IBDV antigen preparation

The live intermediate type strain vaccine (Ventri Biologicals, Pune) virus in suitable dilution was used as the antigen. Water in oil emulsion of IBDV antigens was made in Freund's complete (FCA) or incomplete (FIA) adjuvant so as to contain $1 \mathrm{mg}$ protein per $\mathrm{ml}$ for rabbit immunization and $100 \mu \mathrm{g}$ protein per $1 \mathrm{ml}$ for mice.

\section{Immunization schedule}

Pre-immune serum from each animal was collected as a negative control. The rabbit immunization schedule to raise hyperimmune sera (HIS) against IBDV antigens is given in table 1 and mice immunization schedule is given in table 2 . Water in oil emulsion of IBDV antigen in FCA was injected subcutaneously and intramuscular at multiple sites. The second, third and fourth booster injections of the same dose but in FIA were given at 15 days interval after the first injection. Ten days after the last booster, final bleeding was done by cardiac puncture under anesthesia with Ketamine and Xylazine.

\begin{tabular}{|c|c|c|c|c|c|}
\hline Day & $\begin{array}{c}\text { Antigen given per } \\
\text { rabbit }\end{array}$ & $\begin{array}{c}\text { Adjuvant } \\
\text { used }\end{array}$ & $\begin{array}{c}\text { Volume of emulsion } \\
\text { used }\end{array}$ & Site of injection & Route of administration \\
\hline 0 & $1 \mathrm{mg}$ & FCA & $1.0 \mathrm{ml}$ & Both thighs & $\mathrm{s} / \mathrm{c}, \mathrm{i} / \mathrm{m}$ \\
\hline 15 & $1 \mathrm{mg}$ & FIA & $1.0 \mathrm{ml}$ & Both thighs & $\mathrm{s} / \mathrm{c}, \mathrm{i} / \mathrm{m}$ \\
\hline 30 & $1 \mathrm{mg}$ & FIA & $1.0 \mathrm{ml}$ & Both thighs & $\mathrm{s} / \mathrm{c}, \mathrm{i} / \mathrm{m}$ \\
\hline 40 & $1 \mathrm{mg}$ & $\begin{array}{c}\text { No adju- } \\
\text { vant }\end{array}$ & $500 \mu \mathrm{l}$ & Ear vein & $\mathrm{i} / \mathrm{v}$ \\
\hline 42 & \multicolumn{5}{|c|}{ Final bleeding under anesthesia with Ketamine and Xylazine } \\
\hline 52 & \multicolumn{5}{|c|}{} \\
\hline
\end{tabular}

Table 1: Immunization schedule for rabbits.

\begin{tabular}{|c|c|c|c|c|c|}
\hline Day & Antigen given per mouse & $\begin{array}{c}\text { Adjuvant } \\
\text { used }\end{array}$ & Site of injection & $\begin{array}{c}\text { Volume of antigen } \\
\text { used }\end{array}$ & $\begin{array}{c}\text { Routes of } \\
\text { administration }\end{array}$ \\
\hline 0 & $100 \mu \mathrm{g}$ & FCA & $50 \mu \mathrm{g}-\mathrm{I} / \mathrm{M}$ & $500 \mu \mathrm{l}-\mathrm{s} / \mathrm{c}$ and $\mathrm{i} / \mathrm{m}$ & $\mathrm{s} / \mathrm{c}, \mathrm{i} / \mathrm{m}, \mathrm{i} / \mathrm{p}$ \\
\hline 15 & $100 \mu \mathrm{g}$ & FIA & $50 \mu \mathrm{g}-\mathrm{I} / \mathrm{M}$ & $500 \mu \mathrm{l}-\mathrm{s} / \mathrm{c}$ and $\mathrm{i} / \mathrm{m}$ & $\mathrm{s} / \mathrm{c}, \mathrm{i} / \mathrm{m}, \mathrm{i} / \mathrm{p}$ \\
\hline 30 & $100 \mu \mathrm{g}$ & FIA & $50 \mu \mathrm{g}-\mathrm{I} / \mathrm{M}$ & $500 \mu \mathrm{l}-\mathrm{s} / \mathrm{c}$ and $\mathrm{i} / \mathrm{m}$ & $\mathrm{s} / \mathrm{c}, \mathrm{i} / \mathrm{m}, \mathrm{i} / \mathrm{p}$ \\
\hline 40 & $100 \mu \mathrm{g}$ & & $\& \mathrm{~S} / \mathrm{C} ; 50 \mu \mathrm{g}-\mathrm{peritoneum}$ & $500 \mu \mathrm{l}-\mathrm{i} / \mathrm{p}$ & \\
\hline 45 & $\begin{array}{c}\text { Final bleeding by heart puncture } \\
\text { with chloroform anesthesia }\end{array}$ & & $50 \mu \mathrm{g}-\mathrm{I} / \mathrm{M}$ & $500 \mu \mathrm{l}-\mathrm{s} / \mathrm{c}$ and $\mathrm{i} / \mathrm{m}$ & $\mathrm{s} / \mathrm{c}, \mathrm{i} / \mathrm{m}, \mathrm{i} / \mathrm{p}$ \\
\hline
\end{tabular}

Table 2: Immunization schedule for mice. 


\section{Specificity test for the hyperimmune sera}

The specificity of hyperimmune sera against IBDV was ensured by performing agar gel precipitation test (AGPT) as per method of Hirai and Shimakura [5] (Figure 2).

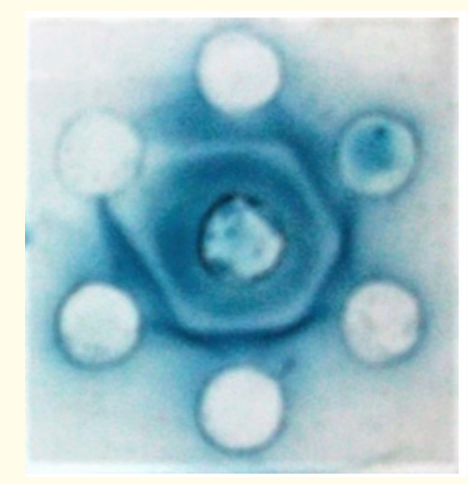

Figure 2: AGPT with serum showing precipitin lines of antibodies with IBDV.

Wells 1, 2, 3, 4, 5 (clockwise from top) contain anti IBDV hyperimmune serum and 6 th well is control i.e. without serum.

Immunofluorescence staining

The standard immunofluorescence staining protocol [6] was followed with minor modifications.

\section{Study on the effect of B cell activation on IBDV binding}

Bursae were excised and collected in HBSS from the healthy broiler birds at the time of slaughtering. Immediately after collection of bursa, it was thoroughly rinsed in HBSS, dissected free of fat and capsule and transferred to fresh HBSS. After removing capsule, it was chopped with fine scissors. The finely chopped tissue was processed further as per the method of Potworowski [7] and Hirai and Calnek [8]. The minced tissue was gently forced through a 60 $\mu \mathrm{m}$ pore sized steel wire mesh. To obtain a single cell suspension it was passed through $24 \mathrm{G}$ needle to dissociate the cellular aggregates into individual cells.

The lymphoid and non-lymphoid bursal cell populations were separated by density gradient centrifugation using Ficoll Hypaque (Sigma, USA) as per the standard method [9]. The bursal cell suspension was layered onto Ficoll-Hypaque (3:1) and centrifuged at $2000 \mathrm{rpm}$ for 20 minutes at $10^{\circ} \mathrm{C}$. After centrifugation, the white lymphoid cell layer at the junction of plasma and Ficoll was col- lected carefully and was washed thrice with PBS by centrifugation at $2500-3000 \mathrm{rpm}$ for 10 minutes.

Immunofluorescence staining was employed for detection of IBDV binding to lymphocytes. The cell pellet was resuspended in PBS to determine the cell viability and concentration. The number of viable cells in a cell suspension was determined by Trypan blue dye exclusion method. One drop of stained cell suspension (50 $\mu \mathrm{l}$ trypan blue, $5 \mu$ l cell suspension and $45 \mu \mathrm{l}$ PBS) was loaded onto a hemocytometer and viable (unstained) and dead (stained) cells were counted. The percentage of viable cells was determined and the viable cell concentration was adjusted to $2 \times 10^{6}$ cells $/ \mathrm{ml}$.

The bursal lymphocyte suspension $\left(2 \times 10^{6}\right.$ cells $\left./ \mathrm{ml} ; 500 \mu \mathrm{l}\right)$ was centrifuged at $2500-3000 \mathrm{rpm}$ for 30 minutes. The supernatant was discarded and the cell pellet was incubated with Lipopolysaccharide (Sigma, U.S.A.; $20 \mu \mathrm{l}$ of $50 \mathrm{mg} / \mathrm{ml}$ ) for $1 \mathrm{hr}$ at $37^{\circ} \mathrm{C}$.

For controls, only the diluent was added to the cell suspension. After incubation, two washings were given with PBS. The IBDV was allowed to adsorb over B lymphocytes for $1 \mathrm{hr}$ at $37^{\circ} \mathrm{C}$. After incubation, two washings were given with PBS. The cells were then treated with $100 \mu \mathrm{l}$ of hyperimmune serum against IBDV for $1 \mathrm{hr}$ at $37^{\circ} \mathrm{C}$ followed by two washings with PBS. The cells were then suspended in $200 \mu \mathrm{l}$ of $1 \%$ paraformaldehyde to preserve them for flow cytometric studies. At the time of flow cytometric analysis, two washings were given with PBS. The cells were then suspended in Fluorochrome (FITC or TRITC) - conjugated anti rabbit antibody (Genei, Bangalore) diluted (1:40) in PBS and incubated at $4{ }^{\circ} \mathrm{C}$ for $1 \mathrm{hr}$ followed by two washings. The cells were finally suspended in PBS. The intensity and percentage of B cells bound with IBDV in control and LPS treated cell suspension was compared by fluorescence microscopy on a U V microscope (Nikon) and flow cytometry on FACS Caliber (Becton Dickinson, Franklin Lakes, NJ, USA). The data was processed using Cell Quest Software (Becton Dickinson). The percentage and intensity of positive cells was calculated.

\section{Exploration of IBDV binding on activated T lymphocytes}

About $10 \mathrm{ml}$ blood was collected from healthy broiler birds in $2 \%$ EDTA in PBS at the time of slaughtering. Blood was centrifuged at $2500 \mathrm{rpm}$ for 10 minutes. Plasma was discarded and the buffy coat was separated from the centrifuged blood. To separate the peripheral blood mononuclear cells, density gradient centrifugation on Ficoll Hypaque (Sigma, USA) was employed following the standard method. The buffy coat was overlayered onto Ficoll hypaque 
(3:1) and centrifuged at $2000-2500 \mathrm{rpm}$ for 20 minutes at $10^{\circ} \mathrm{C}$. After centrifugation, the white layer of mononuclear cells at the junction of plasma and Ficoll was harvested and washed thrice with PBS.

\section{Immunofluorescence staining}

Immunofluorescence staining of the cells was employed for detection of IBDV binding to lymphocytes. The lymphocyte count was adjusted to $2 \times 10^{6}$ cells and was treated with Concanavalin A (Sigma, USA; $10 \mu \mathrm{l}$ of $25 \mathrm{mg} / \mathrm{ml}$ ) for one and a half hrs. at $37^{\circ} \mathrm{C}$. For controls, only the diluent was added to the cell suspension. After incubation, two washings were given with PBS. The CEF passaged IBDV and anti CD3 antibody raised in rabbit (Sigma, USA; 1:40 dilution in PBS) was allowed to adsorb over activated Tymphocytes for $1 \mathrm{hr}$ at $37^{\circ} \mathrm{C}$. After incubation, two washings were given with PBS. The cells were then treated with $100 \mu \mathrm{l}$ of hyperimmune serum raised against IBDV in mice for $1 \mathrm{hr}$ at $37^{\circ} \mathrm{C}$ followed by two washings with PBS. The cells were then suspended in $200 \mu \mathrm{l}$ of $1 \%$ paraformaldehyde to preserve them for flow cytometric studies. At the time of flow cytometric analysis, two washings were given with PBS. The cells were then suspended in Fluorochrome (FITC or TRITC) conjugated anti rabbit antibody for anti-CD3 antibody and anti-mouse antibody for the anti-IBDV serum (Genei, Bangalore) diluted (1:40) in PBS and incubated at $4^{\circ} \mathrm{C}$ for $1 \mathrm{hr}$ followed by two washings. The cells were finally suspended in PBS. The simultaneous binding of IBDV and anti CD3 antibody on activated cell suspension was observed under a UV microscope. The percentage of single stained and double stained cells were calculated by flow cytometric analysis.

Study on concurrent expression of MHC II and CD3 on activated T lymphocytes

Immunofluorescent staining was employed for detection of IBDV binding to lymphocytes. The peripheral blood lymphocyte's cell count was adjusted to $2 \times 10^{6}$ cells and was treated with Concanavalin A (Sigma, USA; $10 \mu \mathrm{l}$ of $25 \mathrm{mg} / \mathrm{ml}$ ) for one and a half hrs at $37^{\circ} \mathrm{C}$. The anti-CD3 $\mathrm{T}$ cell antibody raised in rabbit (Sigma, USA; 1:40 dilution in PBS) was allowed to adsorb over activated T lymphocytes for $1 \mathrm{hr}$ at $37^{\circ} \mathrm{C}$ followed by two washings with PBS. The cells were then suspended in $200 \mu \mathrm{l}$ of $1 \%$ paraformaldehyde to preserve them for flow cytometric studies. At the time of flow cytometric analysis, two washings were given with PBS. The cells were then suspended in TRITC conjugated anti-rabbit antibody for antiCD3 antibody (Genei, Bangalore; 1:40 dilution) and anti-chicken MHC II FITC conjugated and cells were incubated at $4^{\circ} \mathrm{C}$ for $1 \mathrm{hr}$ followed by two washings. The cells were finally suspended in PBS. The simultaneous binding of anti-MHC II antibody and anti-CD3 antibody on activated cell suspension was observed under a UV microscope. The percentage of single stained and double stained cells were analyzed by flow cytometry.

Study on the effect of TGF $\beta$ treatment of B cells on IBDV binding

Immunofluorescence staining was employed for detection of IBDV binding to lymphocytes before and after treatment with transforming growth factor beta (TGF- $\beta$ ). The bursal B cell count was adjusted to $2 \times 10^{6}$ cells $/ \mathrm{ml}$. The supernatant was discarded and the cell pellet was incubated with TGF $\beta$ (Merck, U.S.A.; 1: 100 dilution) for $2 \mathrm{hrs}$ at $37^{\circ} \mathrm{C}$. For controls, only the diluent was added to the cell suspension. After incubation, two washings were given with PBS. The CEF passaged IBDV was allowed to adsorb over B lymphocytes for $1 \mathrm{hr}$ at $37^{\circ} \mathrm{C}$. After incubation, two washings were given with PBS. The cells were then treated with $100 \mu 1$ of hyperimmune serum raised against IBDV for $1 \mathrm{hr}$ at $37^{\circ} \mathrm{C}$ followed by two washings with PBS. The cells were then suspended in $200 \mu \mathrm{l}$ of $1 \%$ paraformaldehyde to preserve them for flow cytometric studies. At the time of flow cytometric analysis, two washings were given with PBS. The cells were then suspended in Fluorochrome (FITC or TRITC) - conjugated anti-rabbit antibody (Genei, Bangalore) diluted (1:40) in PBS and incubated at $4^{\circ} \mathrm{C}$ for $1 \mathrm{hr}$ followed by two washings. The cells were finally suspended in PBS. The fluorescence of IBD virus of TGF $\beta$ treated and TGF $\beta$ untreated cell suspension was observed under UV microscope. The intensity and percentage of B cells bound with IBDV in control and TGF $\beta$ treated cell suspension was compared with flow cytometry.

Study on the effect of TGF $\beta$ treatment of B cells on MHC II receptor expression

Immunofluorescence staining was employed for observing MHC II receptor expression on lymphocytes. The bursal B cell count was adjusted to $2 \times 10^{6}$ cells $/ \mathrm{ml}$. The supernatant was discarded and the cell pellet was incubated with TGF $\beta$ (Merck, U.S.A.; 1:100 dilution) for $2 \mathrm{hr}$. at $37^{\circ} \mathrm{C}$. For controls, only the diluent was added to the cell suspension. After incubation, two washings were given with PBS. The cells were then suspended in $200 \mu \mathrm{l}$ of $1 \%$ paraformaldehyde to preserve them for flow cytometric studies. At the time of flow cytometric analysis, two washings were given with PBS. The cells were then suspended in anti-MHC II antibody conjugated with FITC (Serotec, Germany; 1:40 dilution) and incubated at $4^{\circ} \mathrm{C}$ for 1 
$\mathrm{hr}$ followed by two washings. The cells were finally suspended in PBS. The fluorescence for MHC II receptor of TGF $\beta$ treated and TGF $\beta$ untreated cell suspension was observed under UV microscope. The intensity and percentage of B cells positive for MHC II in control and TGF $\beta$ treated cell suspension was compared with flow cytometry.

Study on the effect of IFN $\gamma$ treatment of B cells on IBDV binding

Immunofluorescence staining was employed for detection of IBDV binding to lymphocytes. The bursal B cell count was adjusted to $2 \times 10^{6}$ cells $/ \mathrm{ml}$. The supernatant was discarded and the cell pellet was incubated with Interferon Gamma (IFN $\gamma$; Merck, U.S.A.; 1: 100 dilutions) for $2 \mathrm{hrs}$ at $37^{\circ} \mathrm{C}$. For controls, only the diluent was added to the cell suspension. After incubation, two washings were given with PBS. The IBD virus was allowed to adsorb over B lymphocytes for $1 \mathrm{hr}$ at $37^{\circ} \mathrm{C}$. After incubation, two washings were given with PBS. The cells were then treated with $100 \mu 1$ of hyperimmune serum raised against IBDV for $1 \mathrm{hr}$ at $37^{\circ} \mathrm{C}$ followed by two washings with PBS. The cells were then suspended in $200 \mu \mathrm{l}$ of $1 \%$ paraformaldehyde to preserve them for flow cytometric studies. At the time of flow cytometric analysis, two washings were given with PBS. The cells were then suspended in Fluorochrome (FITC or TRITC) - conjugated anti-rabbit antibody (Genei, Bangalore) diluted $(1: 40)$ in PBS and incubated at $4^{\circ} \mathrm{C}$ for $1 \mathrm{hr}$ followed by two washings. The fluorescence of IBD virus of IFN $\gamma$ treated and IFN $\gamma$ untreated cell suspension was observed under UV microscope. The cells were finally suspended in PBS. The intensity of B cells bound with IBDV in control and IFN $\gamma$ treated cell suspension was compared by flow cytometry.

Study on the effect of IFN $\gamma$ treatment of B cells on MHC II receptor expression

Immunofluorescence staining was employed for MHC II receptor expression on lymphocytes. The bursal B cell count was adjusted to $2 \times 10^{6}$ cells $/ \mathrm{ml}$. The supernatant was discarded and the cell pellet was incubated with IFN $\gamma$ (Merck, U.S.A.; 1:100 dilutions) for $2 \mathrm{hr}$ at $37^{\circ} \mathrm{C}$. For controls, only the diluent was added to the cell suspension. After incubation, two washings were given with PBS. The cells were then suspended in $200 \mu \mathrm{l}$ of $1 \%$ paraformaldehyde to preserve them for flow cytometric studies. At the time of flow cytometric analysis, two washings were given with PBS. The cells were then suspended in anti-MHC II antibody conjugated with FITC (Serotec, Germany; 1:40 dilution) and incubated at $4^{\circ} \mathrm{C}$ for 1 $\mathrm{hr}$ followed by two washings. The cells were finally suspended in PBS. The fluorescence for MHC II receptor of IFN $\gamma$ treated and IFN $\gamma$ untreated cell suspension was observed under UV microscope. The intensity and percentage of B cells positive for MHC II in control and IFN $\gamma$ treated cell suspension was compared by flow cytometry.

Study on pre incubation of B cells with IBD virus and MHC II receptor staining

Immunofluorescence staining was employed for observing the MHC II receptor staining on lymphocytes. The bursal B cell count was adjusted to $2 \times 10^{6}$ cells $/ \mathrm{ml}$. The supernatant was discarded and the cell pellet was incubated with $200 \mu \mathrm{l}$ of IBD virus for $1 \mathrm{hr}$ at $37^{\circ} \mathrm{C}$. For controls, only the diluent was added to the cell suspension. After incubation, two washings were given with PBS. The cells were then suspended in $200 \mu \mathrm{l}$ of $1 \%$ paraformaldehyde to preserve them for flow cytometric studies. At the time of flow cytometric analysis, two washings were given with PBS. The cells were then suspended in anti-MHC II antibody conjugated with FITC (Serotec, Germany; 1:40 dilution) and incubated at $4^{\circ} \mathrm{C}$ for $1 \mathrm{hr}$ followed by two washings. The cells were finally suspended in PBS. The MHC II receptor staining in IBDV pre-incubated and without IBDV pre-incubated samples were observed under U V microscope. The intensity and percentage of B cells positive for MHC II in control and IBD virus treated cell suspension was compared by flow cytometric studies.

Study on effect of B cell treatment with anti-MHCII antibody on IBDV binding

Immunofluorescence staining was employed for detection of IBDV binding to lymphocytes. The bursal B cell count was adjusted to $2 \times 10^{6}$ cells $/ \mathrm{ml}$. The supernatant was discarded and the cell pellet was incubated with anti-MHC II antibody (Seotec, Germany; 1 : 100 dilution) for $1 \mathrm{hr}$ at $37^{\circ} \mathrm{C}$. For controls, only the diluent was added to the cell suspension. After incubation, two washings were given with PBS. The IBD virus was allowed to adsorb over B lymphocytes for $1 \mathrm{hr}$ at $37^{\circ} \mathrm{C}$. After incubation, two washings were given with PBS. The cells were then treated with $100 \mu \mathrm{l}$ of hyperimmune serum raised against IBDV for $1 \mathrm{hr}$ at $37^{\circ} \mathrm{C}$ followed by two washings with PBS. The cells were then suspended in $200 \mu \mathrm{l}$ of $1 \%$ paraformaldehyde to preserve them for flow cytometric studies. At the time of flow cytometric analysis, two washings were given with PBS. The cells were then suspended in Fluorochrome (FITC or TRITC) conjugated anti-rabbit antibody (Genei, Bangalore) diluted 
(1:40) in PBS and incubated at $4^{\circ} \mathrm{C}$ for $1 \mathrm{hr}$ followed by two washings. The cells were finally suspended in PBS. The fluorescence of IBDV in control and MHC II antibody treated cell suspension was observed under U V microscope. The intensity of B cells bound with IBDV in control and MHC II antibody treated cell suspension was compared by flow cytometry.

\section{Results and Discussion}

Effect of LPS activation of lymphocytes on binding of IBD virus to the cells

The effect of activation of chicken lymphocytes with lipopolysaccharide (LPS) on IBDV binding was studied by immunofluorescence staining and UV microscopy and enumerating the IBDV bound cells and by quantitating the intensity of fluorescence due to IBDV binding on lymphocytes through flow cytometry. It was found that the binding of IBDV was enhanced after activation of lymphocytes with LPS. The mean percentage of IBDV bound lymphocytes in the bursal cell suspension was $22.96 \pm 4.12$ without LPS treatment and $34.24 \pm 6.01$ after LPS treatment (Figure 3 and 4). The difference was found to be highly significant ( $p<0.005)$. The mean intensity of IBDV staining on lymphocytes was 7554.61 \pm 411.35 without LPS treatment and $8022.91 \pm 549.80$ after LPS treatment (Figure 5 and 6). The difference was found to be significant $(p<0.05)$. This indicates that there is an upregulation of expression of the putative target molecule on lymphocytes after activation with LPS resulting in enhanced binding of IBDV to the cells. LPS is a polyclonal activator of B cells and induces proliferation of B cells [10]. Thus, the putative target molecule could possibly be a marker of lymphocyte activation.

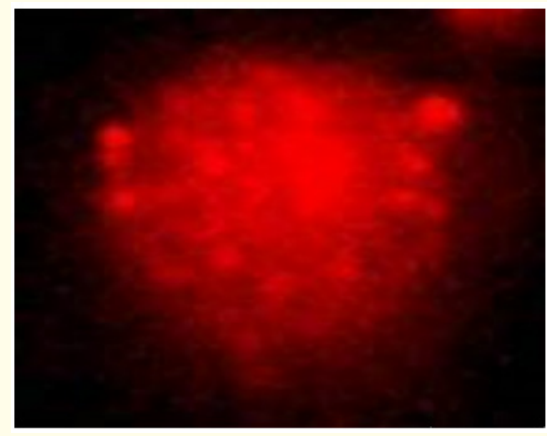

Figure 3: Immunofluorescent staining showing IBDV binding on lymphocytes without LPS treatment.

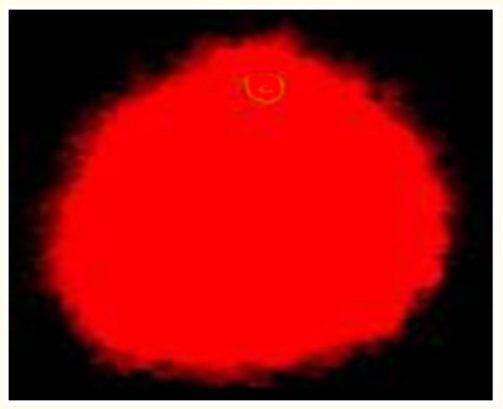

Figure 4: Immunofluorescent staining showing IBDV binding on lymphocytes after LPS treatment.

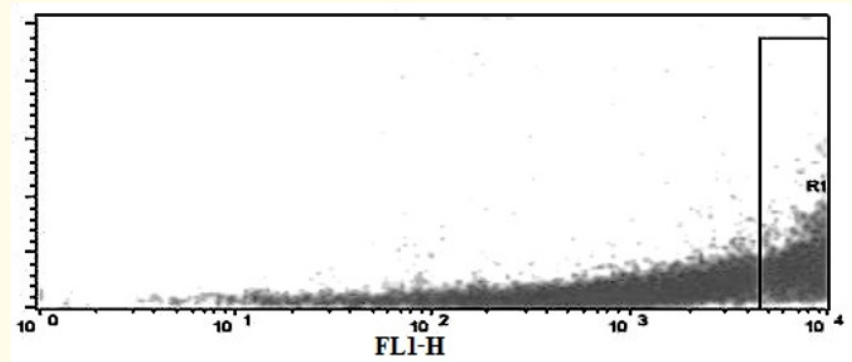

Figure 5: Percentage of IBDV stained lymphocytes without LPS treatment by flow cytometry.

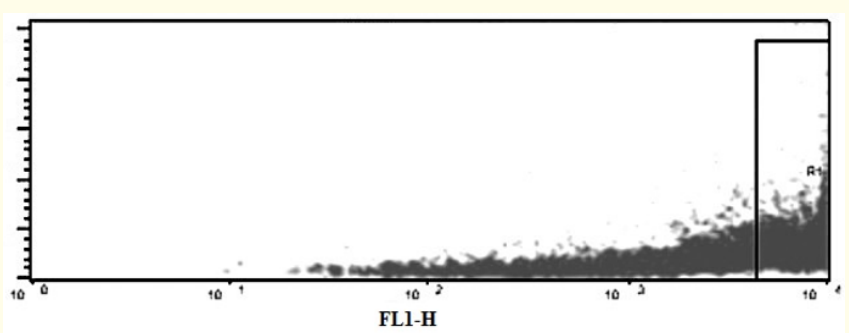

Figure 6: Percentage of IBDV stained lymphocytes after LPS treatment by flow cytometry.

\section{Studies on blocking of the putative target molecule}

Studies on blocking of the putative target were conducted by prior incubation of lymphocytes with IBDV followed by MHC II staining of cells as well as by prior incubation of lymphocytes with unlabeled anti-MHC II antibody followed by exposure of cells to IBDV and staining for IBDV. The stained cells were observed under a UV 
microscope and subjected to flow cytometric analysis. The mean percentage of MHC II $^{+v e}$ lymphocytes was $20.99 \pm 4.25$ without IBD virus treatment and $18.14 \pm 2.87$ after IBD virus treatment. The difference was found to be highly significant $(\mathrm{p}<0.001)$. The mean intensity of MHC II staining on lymphocytes was $327.52 \pm 24.18$ without treatment and 309.16 \pm 20.26 after treatment (Figure 7 and 8 ). The difference was found to be significant ( $p<0.05)$. The class II MHC genes are expressed constitutively in only a few cell types, but they can be induced in majority of the cell types [11]. It has been hypothesized by Gangale and Saxena [12] that the MHC II molecule present on immature B cells and activated lymphocytes as well as on some other susceptible cells could be a possible target for IBDV.

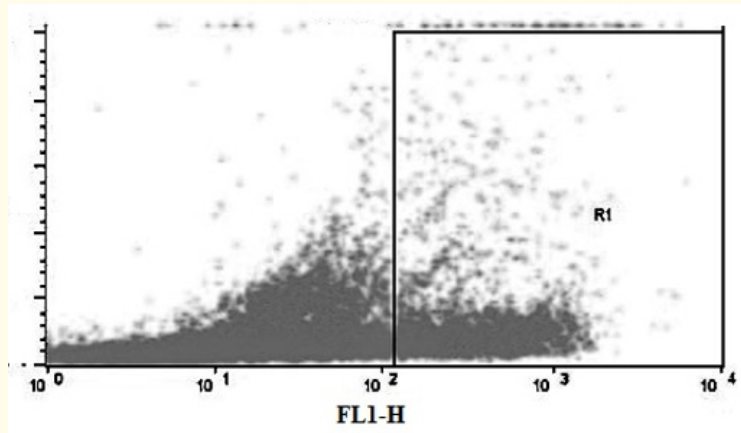

Figure 7: Flow cytometry histogram showing MHC II +ve lymphocytes without IBDV treatment.

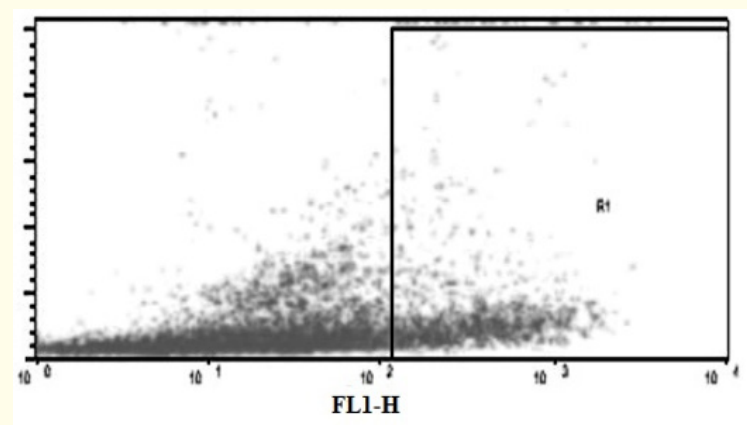

Figure 8: Flow cytometry histogram showing MHC II +ve lymphocytes after IBDV treatment.

The mean percentage of IBDV bound lymphocytes was 19.36 \pm 6.25 without anti-MHC II antibody treatment and $14.77 \pm 7.28$ after anti-MHC II antibody treatment. The difference was found to be non-significant. The mean intensity of IBDV staining on lymphocytes was $4327.00 \pm 1212.62$ without anti-MHC II antibody treatment and 3469.47 \pm 1355.55 after anti-MHC II antibody treatment (Figure 9 and 10). The difference was found to be non-significant. Thus, there was a highly significant decrease in MHC II staining after prior incubation of lymphocytes with IBDV and a non-significant decrease in IBDV binding on lymphocytes after prior incubation of cells with unlabeled anti-MHC II antibody. These findings only substantiate the earlier results pointing to the identity of the putative target molecule. However, there is a need for further studies to determine the optimum concentration and incubation time for achieving an accurate assessment.

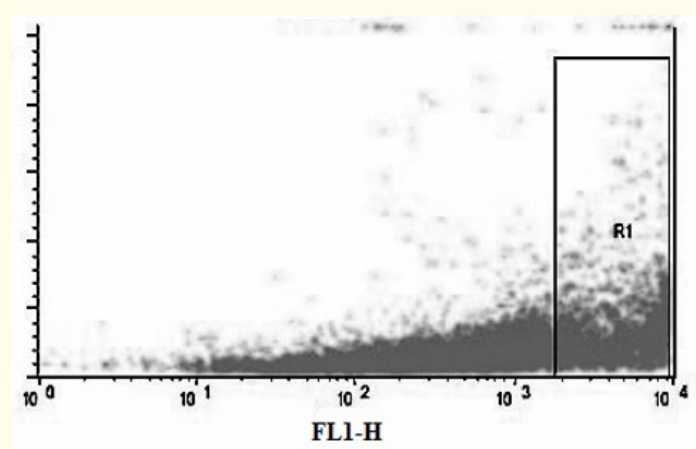

Figure 9: Flow cytometry histogram showing percentage of IBDV stained lymphocytes without anti MHC II antibody treatment.

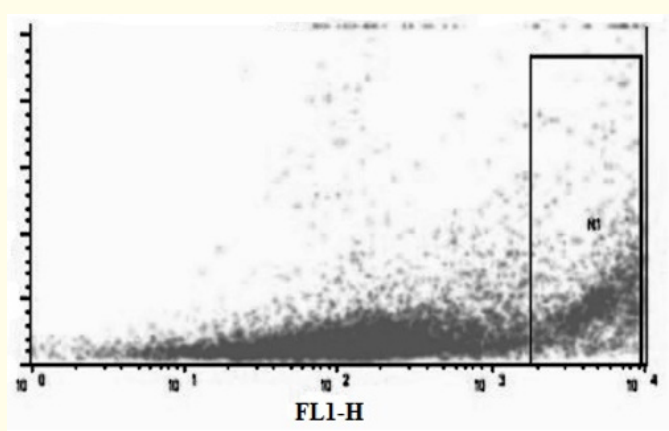

Figure 10: Flow cytometry histogram showing percentage of IBDV stained lymphocytes after anti MHC II antibody treatment.

\section{Effect of TGF- $\beta$ on MHC II expression on lymphocytes}

Immunofluorescence studies were conducted to determine the effect of TGF $\beta$ on MHC II expression on lymphocytes. The stained 
cells were observed under a UV microscope and subjected to flow cytometric analysis. Kasper and Gatel [13] have reported that TGF $\beta$ may impair IL-12 production and hence MHC II. Lee., et al. [14] also reported that the cytokine TGF $\beta$ inhibits IFN $\gamma$ induced class II MHC expression at the transcriptional level by blocking IFN $\gamma$ induced CIITA mRNA accumulation. The mean percentage of MHC II stained lymphocytes was $24.46 \pm 5.54$ without TGF treatment and $20.07 \pm 5.40$ after TGF treatment. The difference was found to be highly significant ( $<<0.005)$. The mean intensity of MHC II staining on lymphocytes was $370.00 \pm 17.68$ without TGF treatment and $321.06 \pm 27.01$ after TGF treatment (Figure 11 and 12). The difference was found to be very significant $(p<0.01)$. The results clearly indicate that TGF- $\beta$ very significantly downregulated the expression of MHC II on lymphocytes.

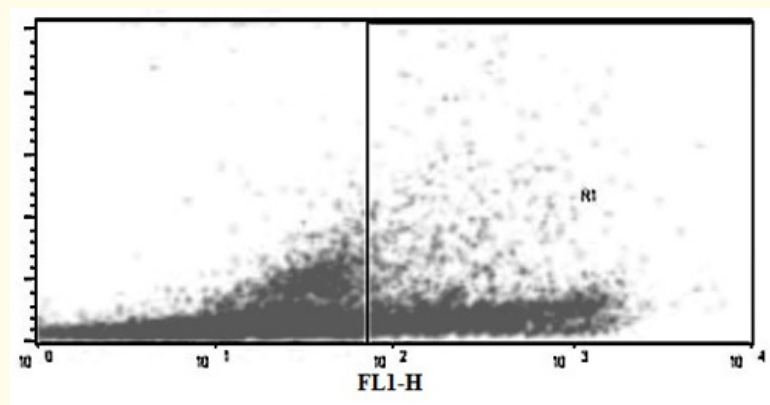

Figure 11: Flow cytometry histogram showing percentage of MHC II +ve lymphocytes without TGF $\beta$ treatment.

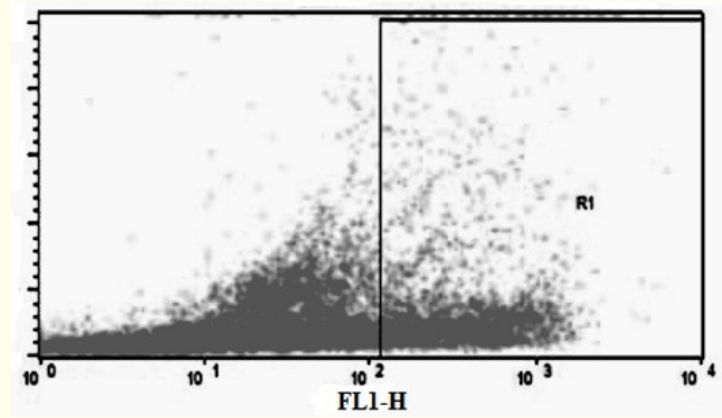

Figure 12: Flow cytometry histogram showing percentage of MHC II +ve lymphocytes after TGF $\beta$ treatment.

Effect of TGF- $\beta$ treatment of lymphocytes on IBDV binding to the cells

Since TGF- $\beta$ is known to downregulate MHC expression on cells, the effect of TGF- $\beta$ treatment of lymphocytes on IBDV binding to cells was studied. The mean percentage of IBDV bound lymphocytes was $21.42 \pm 4.80$ without TGF treatment and $16.12 \pm 3.99$ after TGF treatment (Figure 13 and 14). The difference was found to be highly significant $(\mathrm{p}<0.005)$. The mean intensity of IBDV staining on lymphocytes was $8253.64 \pm 353.39$ without TGF treatment and $7136.88 \pm 1448.66$ after TGF treatment (Figure 15 and 16). The difference was found to be significant $(\mathrm{p}<0.05)$. As evident from the results, there was a significant decrease in the percentage of IBDV bound cells as well as in the level of IBDV binding to cells after treatment of lymphocytes with TGF- $\beta$. Thus, downregulation of MHC II on lymphocytes by TGF- $\beta$ decreases IBDV binding to cells. However, there is a need for further studies to determine the optimum concentration of TGF- $\beta$ and time of exposure of cells to TGF- $\beta$ to assess the effect accurately.

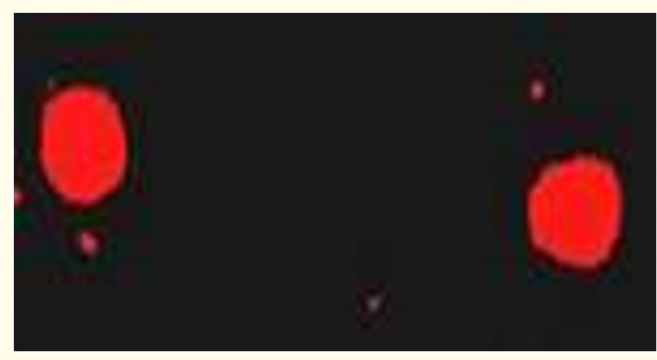

Figure 13: Immunofluorescent staining showing IBDV binding on lymphocytes without TGF $\beta$ treatment.

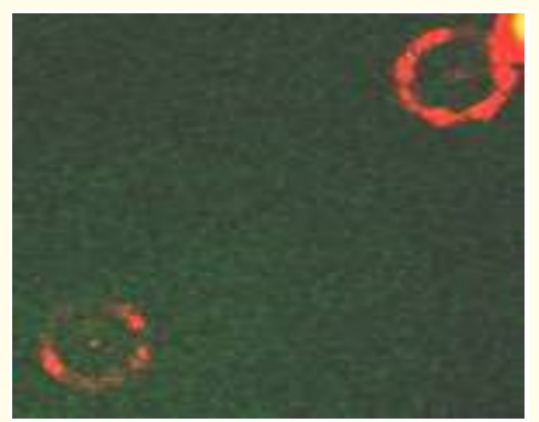

Figure 14: Immunofluorescence staining showing IBDV binding on lymphocytes after TGF $\beta$ treatment.

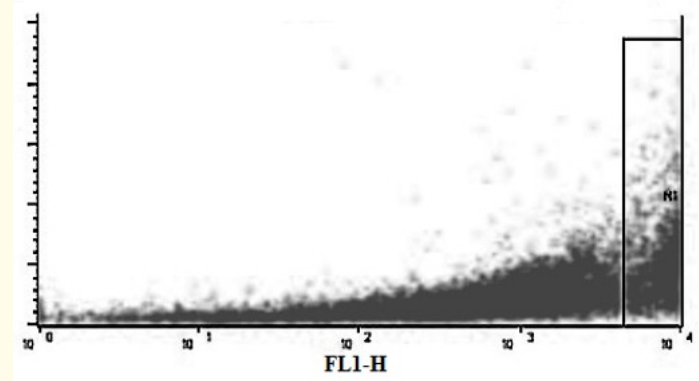

Figure 15: Flow cytometry histogram showing percentage of IBDV stained lymphocytes without TGF $\beta$ treatment. 


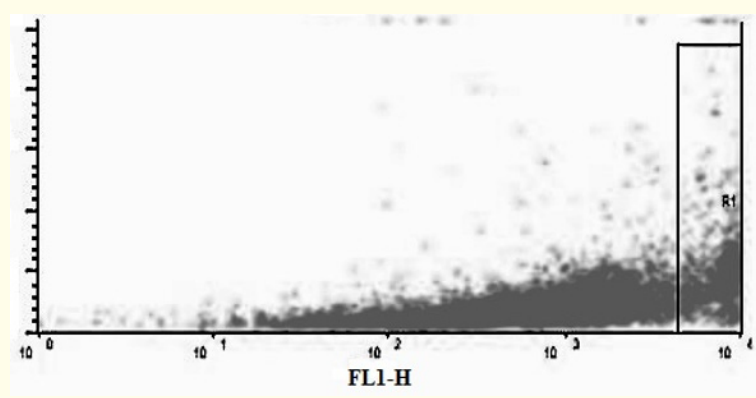

Figure 16: Flow cytometry histogram showing percentage of IBDV stained lymphocytes after TGF $\beta$ treatment.

The effect of Interferon- $\gamma$ treatment of lymphocytes on MHC II expression on cells

The effect of Interferon- $\gamma$ treatment of chicken lymphocytes on MHC II expression on the cells was studied by immunofluorescence. The stained cells were observed under a UV microscope and subjected to flow cytometric analysis.

In our study, enhanced expression of MHC II as well as IBDV binding on lymphocytes was observed after treatment with Interferon- $\gamma$. The mean percentage of MHC II $^{\text {ve }}$ lymphocytes was $5.08 \pm 2.35$ without IFN treatment and $6.50 \pm 2.88$ after treatment (Figure 17 and 18). The difference was found to be significant ( $\mathrm{p}<$ 0.05 ). The mean intensity of MHC II staining on lymphocytes was $376.31 \pm 79.56$ without IFN treatment and $538.60 \pm 217.36$ after IFN treatment. The difference was found to be non-significant. Although there was a significant increase in the number of cells expressing MHC II after treatment of lymphocytes with Interferon- $\gamma$, the increase in the intensity of MHC II staining on cells after the treatment was non-significant. However, there is a need for further studies to determine the optimum concentration of Interferon- $\gamma$ and the time of exposure of cells for accurate assessment of the effects.

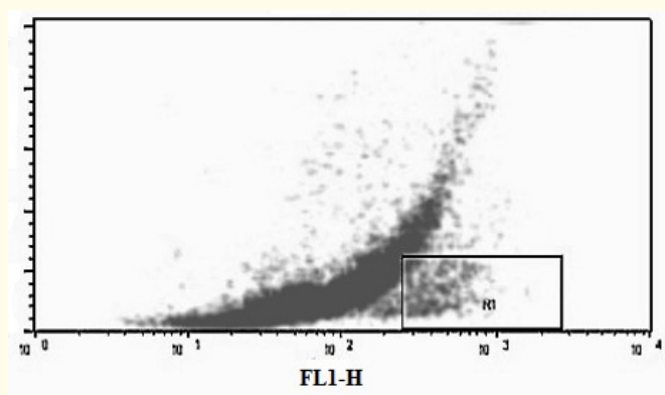

Figure 17: Percentage of MHC II stained lymphocytes without IFN gamma treatment by flow cytometry.

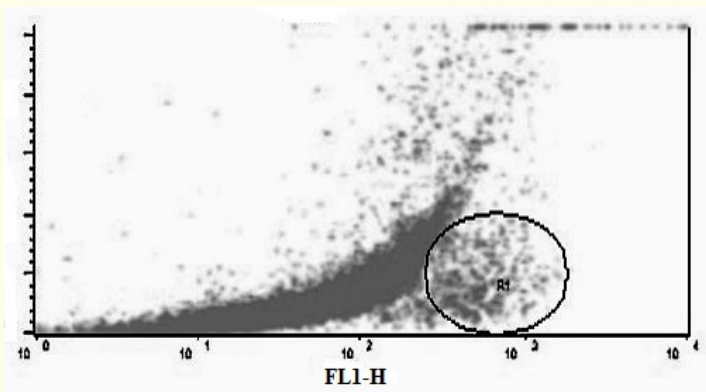

Figure 18: Percentage of MHC II stained lymphocytes after IFN gamma treatment by flow cytometry.

Stiemle., et al. [12] reported that MHC II genes can be induced in majority of cell types by IFN $\gamma$. Collins., et al. [15] showed that IFN $\gamma$ increases the surface expression of HLA-A, B antigens and induces the surface expression of HLA-DR antigens and that IFN $\gamma$ induces parallel expression of two other class II MHC antigens, SB and DC.

Effect of Interferon- $\gamma$ treatment of lymphocytes on IBDV binding on cells

Since Interferon- $\gamma$ up regulates the MHC II expression on cells, the effect of Interferon- $\gamma$ treatment of lymphocytes on IBDV binding to cells was studied. The mean percentage of IBDV bound lymphocytes was $7.46 \pm 1.54$ without IFN treatment and $10.60 \pm 3.50$ after IFN treatment (Figure 19 and 20). The difference was found to be non-significant. The mean intensity of IBDV staining on lymphocytes was $2437.02 \pm 182.05$ without IFN treatment and $2989.16 \pm$ 868.88 after IFN treatment (Figure 21 and 22). The difference was found to be non-significant. Thus, although there was an increase in the number of IBDV bound cells as well as the level of IBDV binding on cells after treatment of lymphocytes with Interferon- $\gamma$, the difference was non-significant. Nevertheless, the findings lend support to the hypothesis that the putative target of IBDV is possibly the MHC II molecule which is upregulated on activation of lymphocytes. However, there is a need of further study to determine the optimum concentration of Interferon- $\gamma$ and the time of exposure of cells to Interferon- $\gamma$ to assess the effect accurately.

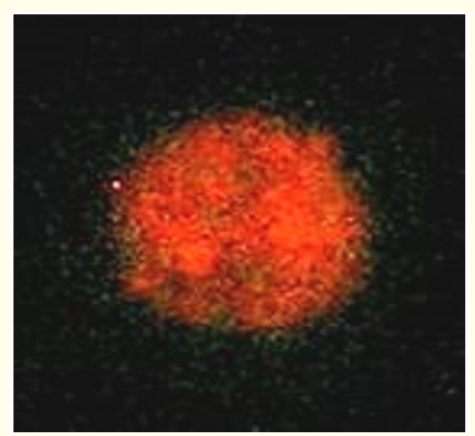

Figure 19: Immunofluorescent staining showing IBDV binding on lymphocytes without IFN $\gamma$ treatment. 


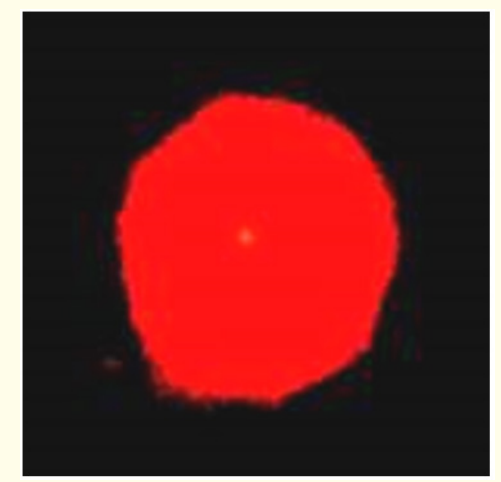

Figure 20: Immunofluorescent staining showing IBDV binding on lymphocytes after IFN $\gamma$ treatment.

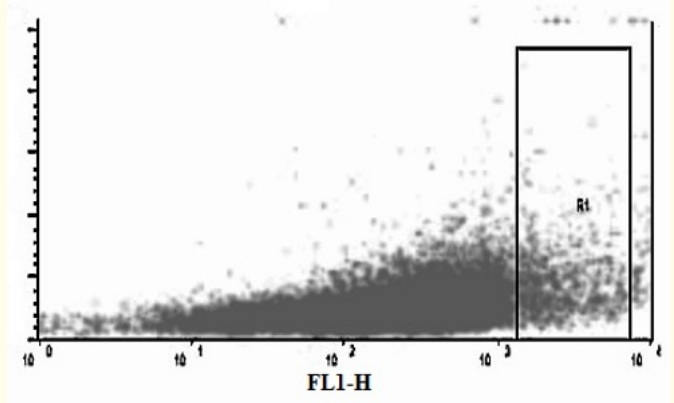

Figure 21: Percentage of IBDV stained lymphocytes without IFN gamma treatment by flow cytometry.

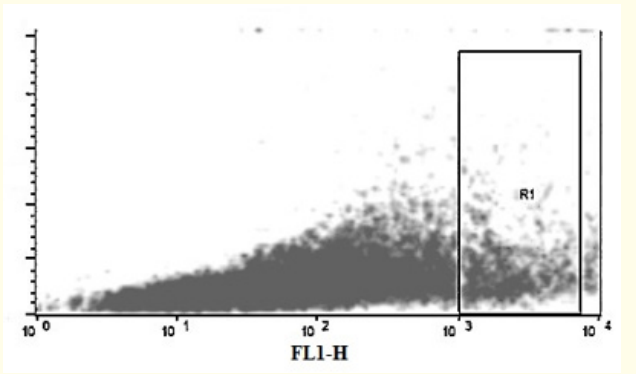

Figure 22: Percentage of IBDV stained lymphocytes after IFN gamma treatment by flow cytometry Binding of IBDV on activated T cells.

Since activated $\mathrm{T}$ cells express MHC II, it was investigated whether IBDV binds to mitogen activated $\mathrm{T}$ lymphocytes or not. Con $\mathrm{A}$ is a polyclonal activator of $\mathrm{T}$ cells and mimics antigen in gen- erating cytotoxic T lymphocytes from normal lymphocytes [16]. It was observed that the activated T cells co-expressed CD3 and MHC II molecules on their surface. Interestingly, a simultaneous expression of CD3 and IBDV binding on activated T lymphocytes was observed for the first time through two color immunofluorescence (Figure 23). The mean percentage of MHC II and CD3 positive lymphocytes was $24.10 \pm 6.45$ and the mean percentage of IBDV and CD3 positive cells was $24.70 \pm 5.12$ (Figure 24 and 25). The difference was found to be non-significant. The results clearly indicated the significant association of MHC II expression and IBDV binding on mitogen activated T lymphocytes.

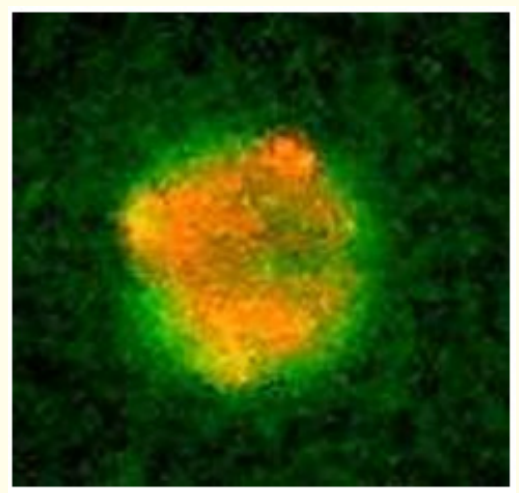

Figure 23: Two color immunofluorescent staining of an activated lymphocyte showing concurrent anti-CD3 (green) and anti-IBDV (red) staining.

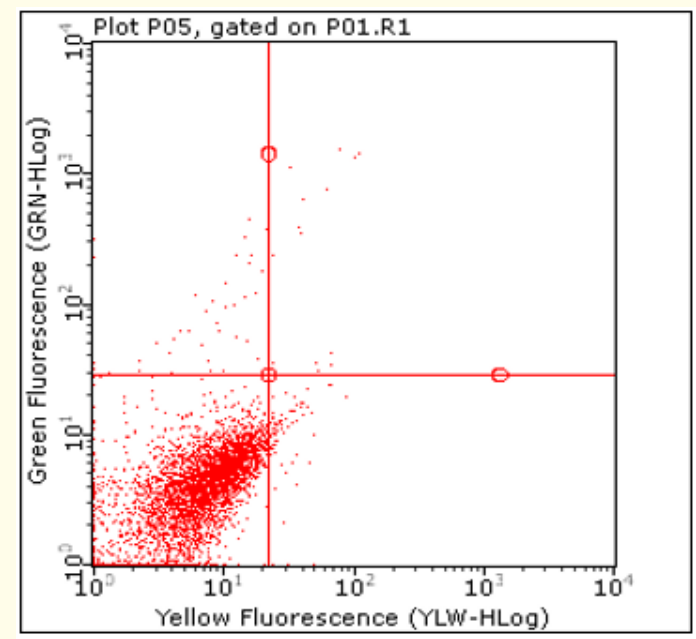

Figure 24: Flow cytometry histogram showing IBDV bound activated CD3 +ve cells. 


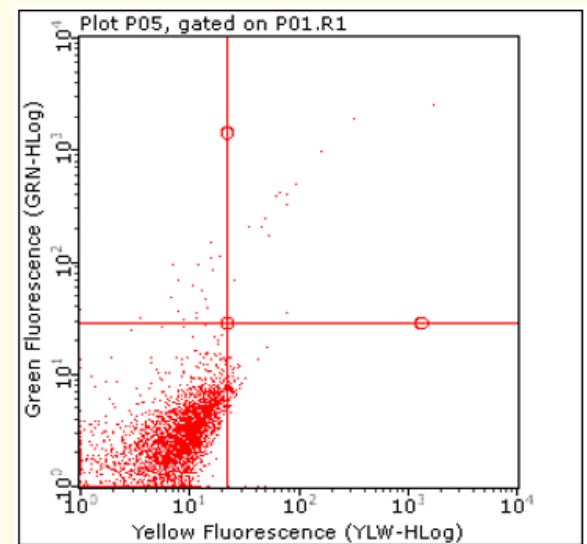

Figure 25: Flow cytometry histogram showing activated $\mathrm{T}$ lymphocytes expressing both MHC II and CD3.

Among the various stages of B cell development, sIgM bearing B cells are the target for the IBDV [17]. However, IBDV infection to the susceptible host cells has not been reported at the level of virus attachment. In addition, specific receptor on the surface of a susceptible host cell for the attachment of IBDV has been elusive. IBDV also invades and replicates in the cells of monocyte-macrophage lineage [18] and chicken bone marrow-derived dendritic cells [19]. Both of these cell types do not bear sIgM. Hence sIgM is unlikely to be the target of IBDV. IBDV is unable to utilize direct membrane fusion to enter the target cells [20].

IBDV causes depletion of B cells by inducing their apoptosis [3]. In general, the binding of lectins on B cells induces apoptosis of $\mathrm{B}$ cells. Thus, it may be possible that IBDV similarly induces apoptosis by attaching to some lectin binding molecules. Chicken heat shock protein 90 (HSP90) on the surface of DF-1 cell membrane has been reported to interact with IBDV particle or VP2-subviral particle (SVP), which is speculated to act as a putative receptor [21]. The Ile-Asp-Ala (IDA) sequence within the VP2 P domain was identified as the functional ligand motif to_4_1 integrin based on a multiple alignment [22]. The_4_1heterodimer is highly abundant in immature lymphocytes [23]. The entry of IBDV has been shown to involve micropinocytosis and trafficking to early endosomes in a Rab5-dependent manner [24].

It has been reported [25] that that there was a persistent depression of MHC II expressing cells in bursa and spleen from 1-day post infection in IBD affected birds. However, there was a rapid in- crease in T cells in Bursa. Zang., et al. [26] demonstrated that HLADQA1 binds to MHC class II on the cell surface, causing MHC class II signaling, initiation of protein kinase $C$ signaling, and mitochondrial membrane depolarization with resultant apoptosis in B cells.

By flow cytometric virus binding assay, Ogawa., et al. [27] showed that the IBDV host range is mainly controlled by the presence of a virus receptor composed of $\mathrm{N}$-glycosylated protein associated with the subtle differentiation stage of B-lymphocytes represented mostly by sIgM-bearing cells.

The possibility of some markers of immature B cells being the target for IBDV binding was studied by Setiyano., et al. [28] by using monoclonal antibodies (T7, Q11 and Q13) against these markers. The monoclonal antibodies T7, Q11 and Q13 against LSCCBK3 cells inhibited the attachment of IBDV to LSCC-BK3 cells. The mAb T7 detected a $119 \mathrm{kD}$ membrane protein of LSCC-BK3 cells, whereas Q11 and Q13 reacted with membrane proteins of molecular weights of 58, 85, 90 and $110 \mathrm{kD}$, respectively. They opined that the protein recognized by all the three antibodies is associated with IBDV binding.

It has been claimed by Lin., et al. (2007) that chicken Heat Shock Protein 90 (Hsp90) is a component of the putative cellular receptor complex of Infectious Bursal Disease Virus. Gangale and Saxena (2007) suggested that T7 antibody may be recognizing some epitopes on B cells which may be target itself or located on or adjacent to the site of IBDV binding. They also showed abrogation of attachment of IBDV to chicken B cells by lectin by incubating the cells with Soybean Agglutinin and Wheat Germ Lectin [29]. Using bioinformatic analysis, Saxena [30] predicted that the target of IBDV could be MHC II molecule. We have now experimentally demonstrated that MHC II, which is present on the surface of bursal lymphoid cells, dendritic cells and mononuclear cells, is indeed the target of IBDV.

\section{Conclusion}

The present study has contributed substantially towards identifying the putative target of IBDV binding on B cells. LPS treatment of $B$ cells resulted in enhanced binding of IBD virus on activated $B$ cells as compared to the untreated cells. TGF $\beta$ downregulated MHC II expression and decreased IBD virus binding on B cells. IFN $\gamma$ upregulated MHC II expression and increased IBD virus binding on B cells. Activation of T cells with Con A led to IBD virus binding on $\mathrm{T}$ cells. Thus, as suggested by the above findings, MHC II molecule may be the putative target for IBDV on chicken B cells. 


\section{Declarations of Interest}

None.

\section{Author Contributions}

HMS conceived the ideas, planned the study, obtained funding, guided the experimentation, analysed and interpreted the results and wrote the manuscript. PK carried out the experimental work.

\section{Acknowledgements}

The study was carried out under a research project (PI: Prof. $\mathrm{H}$ M Saxena) funded by the Department of Biotechnology, Ministry of S\&T, Govt. of India.

\section{Bibliography}

1. Eterradossi N. "Progress in the diagnosis and prophylaxis of infectious bursal disease in poultry". Comprehensive reports on technical items presented to the International Committee or to Regional Commissions. OIE. (1995): 75-82.

2. Kaufer I and Weiss E. "Significance of Bursa of Fabricius as target organ in infectious bursal disease of chickens". Infection and Immunity 27 (1980): 364-67.

3. Jungmann A., et al. "Apoptosis is induced by infectious bursal disease virus replication in productively infected cells as well as in antigen - negative cells in their vicinity". Journal of Genetic Virology 82 (2001): 1107-1115.

4. Tanimura N and Sharma JM. "In situ apoptosis in chickens infected with infectious bursal disease virus". Journal of Comparative Pathology 118 (1998): 15-27.

5. Hirai K and Shimakura S. "Immunodiffusion reaction to avian infectious bursal disease virus". Avian Disease 16 (1972): 961964.

6. Hudson L and Roitt IM. "Immunofluorescent detection of surface antigens specific to T and B lymphocytes in the chicken". European Journal of Immunology 3 (1973): 63.

7. Potworowski E F. "T and B lymphocytes: organ and age distribution in the chicken". Avian Pathology 23 (1972): 199-204.

8. Hirai K and Calnek BW. "In vitro replication of infectious bursal disease virus in established lymphoid cell lines and chicken B lymphocytes". Infection and Immunity 25 (1979): 964-970.

9. Yadava A., et al. "Separation of B and T lymphocytes: Their enumeration and characterization". In: A Handbook of Practical and Clinical Immunology 1 (1992): 219-232.
10. Jaworski M A., et al. "Triggering of affinity- enriched B cells. Analysis of B cell stimulation by antigen - specific helper factor or Lipopolysaccharide I. Dissection into proliferative and differentiative signals". Journal of Experimental Medicine 155 (1982): 248-263.

11. Gangale D P and Saxena H M. "Abrogation of attachment of Infectious Bursal Disease Virus to chicken B cells by treatment of B cells with Soyabean Agglutinin and Wheat Germ Lectin". Internet Journal of Infectious Diseases 6.2 (2008): 1-7.

12. Steimle V., et al. "Regulation of MHC class II expression by interferon-gamma mediated by the transactivator gene CIITA". Science 265.5168 (1994): 106-109.

13. Kasper LH and Gatel DB. "Ups and downs of mucosal cellular immunity against protozoan parasites". Infection and Immunity 69 (2001): 1-8.

14. Lee Y J., et al. "TGF-beta suppresses IFN-gamma induction of class II MHC gene expression by inhibiting class II transactivator messenger RNA expression". Journal of Immunology 158.5 (1997): 2065-2075.

15. Collins T., et al. "Immune interferon activates multiple class II major histocompatibility complex genes and the associated invariant chain gene in human endothelial cells and dermal fibroblasts". Proceedings of the National Academy of Sciences of the United States of America 81 (1984): 4917-4921.

16. Bevan MJ., et al. "H-2 antigen-specific cytotoxic T cell induced by Con A: estimation of their relative frequency". European Journal of Immunology 6 (1976): 150.

17. Rodenberg J., et al. "Flow cytometric analysis of B cell and T cell populations in specific pathogen free chickens infected with infectious bursal disease virus". Avian Disease 38 (1994): 16-21.

18. Inoue M., et al. "Susceptibility of chicken monocytic cell lines to infectious bursal disease virus". Journal of Veterinary Medical Science 54 (1992): 575-577.

19. Liang J., et al. "Chicken bone marrow-derived dendritic cells maturation in response to infectious bursal disease virus". Veterinary Immunology and Immunopathology 164 (2015): 51-55.

20. Moyer CL., et al. "Viral weapons of membrane destruction: Variable modes of membrane penetration by non-enveloped viruses". Current Opinion Virology 1 (2011): 44-49.

21. Lin T., et al. "Chicken heat shock protein 90 is a component of the putative cellular receptor complex of infectious bursal disease virus". Journal of Virology 81 (2007): 8730-8741. 
22. Delgui L., et al. "The capsid protein of infectious bursal disease virus contains a functional alpha 4 beta 1 integrin ligand motif". Virology 386 (2009): 360-372.

23. Rose DM., et al. "2002_4 integrins and the immune response”. Immunology Review 186 (2002): 118-124.

24. Gimenez MC., et al. "Infectious bursal disease virus uptake involves macropinocytosis and trafficking to early endosomes in a Rab5-dependent manner". Cellular Microbiology 17 (2015): 988-1007.

25. Cloud SS., et al. "Immune dysfunction following infection with chicken anemia agent and infectious bursal disease virus. I. Kinetic alterations of avian Lymphocytes subpopulations". Veterinary Immunology and Immunopathology 34 (1992): 337-352.

26. Zang W., et al. "MHC Class II-Mediated Apoptosis by a Nonpolymorphic MHC Class II Peptide Proceeds by Activation of Protein Kinase C". JASN 16.12 (2005): 3661-3668.

27. Ogawa M., et al. "Some characteristics of a cellular receptor for virulent infectious bursal disease virus by using flow cytometry". Archives of Virology 143 (1998): 2327-2341.

28. Setiyano A., et al. "Detection of cell membrane proteins that interact with virulent infectious bursal disease virus". Avian Disease 38 (2001): 16-21.

29. Gangale D P and Saxena H M. "Inhibition of binding of IBD virus to chicken $B$ lymphocytes by antibodies against immature B cell markers". Journal of Immunology and Immunopathology 9 (2007): 50-53.

30. Saxena HM. "Bioinformatic analysis of host pathogen interaction in infectious bursal disease of chickens". European Journal of Biology and Medical Science Research 3.5 (2002): 45-50.

\section{Assets from publication with us}

- Prompt Acknowledgement after receiving the article

- Thorough Double blinded peer review

- Rapid Publication

- Issue of Publication Certificate

- High visibility of your Published work

Website: https://www.actascientific.com/

Submit Article: https://www.actascientific.com/submission.php Email us: editor@actascientific.com

Contact us: +919182824667 